\title{
高強度コンクリートの長期的な長さ変化と中性化に関する研究 \\ LONG-TERM LENGTH CHANGE AND CARBONATION OF HIGH STRENGTH CONCRETE
}

\author{
陣内 浩*, 並木 哲**, 黒岩秀介***, 渡邊悟士**** \\ Hiroshi JINNAI, Satoru NAMIKI, Shusuke KUROIWA \\ and Satoshi WATANABE
}

\begin{abstract}
Experimental studies were performed about a long-term length change and carbonation of high strength concrete. The concretes with waterbinder ratio of $15-65 \%$ were examined. The following conclusions were obtained as results of examination.

1) Length change and weight change of concrete at 6 months became so small that a water-binder ratio becomes low. 2) When the water binder ratio became low, length change of the concrete continued long time. 3) By the accelerated carbonation test, the water portoland cement ratio of the concrete that is not carbonation at 26 weeks was less than about $40 \%$. 4) Even if accelerated carbonation test results of long-term was used, depth of carbonation could be expressed by the function of the square root of age.
\end{abstract}

Keywords: High Strength Concrete, Durability, Long-term, Length Change, Carbonation 高強度コンクリート, 耐久性能, 長期材㱓, 長さ変化, 中性化

1. はじめに

日本で高強度コンクリートが用いられるようになり、約 30 年が 経過した 1)。1990 年代末には設計基準強度 $100 \mathrm{~N} / \mathrm{mm}^{2}$ のコンクリー トが普及しはじめ2!、現在では、現場打設可能な設計基準強度 $150 \mathrm{~N} / \mathrm{mm}^{2}$ のコンクリートが実用段階引に到達している。このような コンクリートの高強度・高耐久性化技術の進歩は、建設省総合プロ ジェクト「鉄筋コンクリート造建物の超軽量·超高層化技術の開発 (通称 New RC 総プロ) 」4) の成果をはじめとする多くの研究者の研 究成果と、構造設計者の努力によるところが大きい。

一方、このような高強度・高耐久性コンクリートを実際の建築物 に適用するにあたっては、従来よりも低い水結合材比のコンクリー トの耐久性能を把握する必要が生じている。また、計画供用年数が 100 年を超える高層 RC 建築物 ${ }^{5}$ も建設されるようになり、従来で はあまり検討されなかった 100 年を超えるような長期材齢での高強 度コンクリートの耐久性能を把握することも重要となっている。し かしながら、このようなデー夕の蓄積には時間がかかり、現在でも デー夕数は十分とはいえない。そこで本論では、水結合材比 15〜 65\%程度のコンクリートの、長期耐久性能に関する基礎的なデー夕 の蓄積を目的として、高強度コンクリートの長期的な長さ変化およ び中性化抵抗性に関して実験的な検討を行った。
2. 長さ変化

2. 1 水結合材比と長さ変化

日本建築学会の建築工事標準仕様書 ·同解説「JASS5 鉄筋コン クリート工事 ${ }^{6)} 19$ 節 高強度コンクリート」(以下 JASS5（19 節） と称す）の本文では、「コンクリートの乾燥収縮は、部材に耐久性 上有害なひび割れが発生する扔それのない範囲とする」と記述され ている。また、同仕様書の解説には、日本建築学会の高耐久性鉄筋 コンクリート造設計施工指針（案）・同解説 ${ }^{7}$ )に示される「材龄 6 ケ 月で乾燥収縮 $7 \times 10^{4}$ 以下 $(0.07 \%$ 以下）」を長さ変化の目安とする ことが記述されている。一般に、コンクリートの長さ変化は使用材 料や単位水量によって異なることが知られている。8) さらに、使用 材料や単位水量を同条件とした場合には、水結合材比が低いほどコ ンクリートの長さ変化は小さくなることが報告されている。9) そこ で、まず筆者らが蓄積したコンクリートの長さ変化試験のデー夕を 整理し、水結合材比と長さ変化率の関係を検討した。

実験に用いた使用材料を表 1 に、コンクリートの調合を表 2 に示 す。ここで使用しているスラダ石毫 ${ }^{10)}$ とは、高温下におけるコン クリートの圧縮強度の改善を目的として用いられる高炉スラグと石 育を混合した混和材（密度：約 $2.9 \mathrm{~g} / \mathrm{cm}^{3}$ 、比表面積：約 $7000 \mathrm{~cm}^{2} / \mathrm{g}$ ) である。実験を行った調合は 71 調合とした。いずれも

\footnotetext{
* 大成建設(株)技術センター 主任研究員・博士 (工学)

** 大成建設侏技術センター 材料チームリーダ-

*** 大成建設(侏技術センター 主任研究貝・工修

**** 大成建設侏技術センター- 研究員・工修
}

Senior Research Engineer, Technology Center, Taisei Corp., Dr. Eng. Material Team Reader, Technology Center, Taisei Corp.

Senior Research Engineer, Technology Center, Taisei Corp., M. Eng. Research Engineer, Technology Center, Taisei Corp., M. Eng. 
表 1 使用材料

\begin{tabular}{|c|c|c|c|}
\hline \multirow{5}{*}{ 結合材 } & 普通ポルトランドセメント (OP) & \multicolumn{2}{|l|}{ 密度 $3.15 \sim 3.16 \mathrm{~g} / \mathrm{cm}^{3}$} \\
\hline & 早強ポルトランドセメント (HP) & \multicolumn{2}{|l|}{ 密度 $3.13-3.14 \mathrm{~g} / \mathrm{cm}^{3}$} \\
\hline & フライアッシュ (FA) & \multicolumn{2}{|l|}{ 密度 $2.2 \sim 2.4 \mathrm{~g} / \mathrm{cm}^{3}$} \\
\hline & スラグ石亳（SG） & \multicolumn{2}{|l|}{ 密度 $2.91 \sim 2.92 \mathrm{~g} / \mathrm{cm}^{3}$} \\
\hline & シリカフューム (SF) & \multicolumn{2}{|l|}{ 密度 $2.2 \mathrm{~g} / \mathrm{cm}^{3}$} \\
\hline \multirow{8}{*}{ 骨 材 } & & 砕 石 & 砕 砂 \\
\hline & 硬質砂岩系砕石・砕砂 & 絶乾密度 $2.62 \sim 2.73 \mathrm{~g} / \mathrm{cm}^{3}$ 、吸水率 $0.42 \sim 0.79 \%$ & 絶乾密度 $2.56-2.62 \mathrm{~g} / \mathrm{cm}^{3}$ 、吸水率 $1.07 \sim 1.58 \%$ \\
\hline & 石灰岩采砕石・砕砂 & 絶乾密度 $2.68 \sim 2.70 \mathrm{~g} / \mathrm{cm}^{3} 、$ 吸水率 $0.35 \sim 0.85 \%$ & 絶乾密度 $2.65 \mathrm{~g} / \mathrm{cm}^{3}$ 、吸水率 $0.52 \%$ \\
\hline & 安山岩系砕石・砕砂 & 絶乾密度 $2.48 \sim 2.67 \mathrm{~g} / \mathrm{cm}^{3}$ 、吸水率 $1.91 \sim 3.29 \%$ & 絶乾密度 $2.60 \mathrm{~g} / \mathrm{cm}^{3}$ 、吸水率 $2.28 \%$ \\
\hline & 石英系砕石・砕砂 & 絶乾密度 $2.43 \sim 2.60 \mathrm{~g} / \mathrm{cm}^{3}$ 、吸水率 $0.64 \sim 3.11 \%$ & 絶乾密度 $2.44 \sim 2.45 \mathrm{~g} / \mathrm{cm}^{3}$ 、吸水率 $2.99 \sim 4.91 \%$ \\
\hline & 流紋岩系砕石·砕砂 & 絶乾密度 $2.59 \sim 2.61 \mathrm{~g} / \mathrm{cm}^{3}$ 、吸水率 $0.75 \sim 0.91 \%$ & 絶乾密度 $2.47 \mathrm{~g} / \mathrm{cm}^{3}$ 、吸水率 $2.63 \%$ \\
\hline & 結晶片岩系砕石・砕砂 & 絶乾密度 $2.72 \mathrm{~g} / \mathrm{cm}^{3}$ 、吸水率 $0.95 \%$ & 絶乾密度 $2.62 \mathrm{~g} / \mathrm{cm}^{3}$ 、吸水率 $1.97 \%$ \\
\hline & 天然砂 & \multicolumn{2}{|l|}{ 䋓乾密度 $2.44-2.70 \mathrm{~g} / \mathrm{cm}^{3}$ 、吸水率 $0.42-2.73 \%$} \\
\hline
\end{tabular}

表 2 調合（長さ変化試験）

\begin{tabular}{|c|c|c|c|c|c|c|}
\hline \multirow{2}{*}{ 結合材* } & \multirow{2}{*}{ 粗骨材 } & \multirow{2}{*}{$\begin{array}{l}\text { W/B } \\
(\%)\end{array}$} & \multicolumn{4}{|c|}{ 単位䛼 $\left(\mathrm{kg} / \mathrm{m}^{3}\right)$} \\
\hline & & & 水 & 結会材 & 糂骨材 & 緗楅材 \\
\hline $\mathrm{OP}$ & 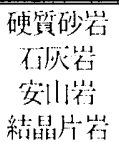 & $\begin{array}{c}22 \\
65\end{array}$ & $\begin{array}{l}155 \\
-28\end{array}$ & $\begin{array}{c}285 \\
682\end{array}$ & $\begin{array}{l}798 \\
1077\end{array}$ & $\begin{array}{c}626 \\
933\end{array}$ \\
\hline $\begin{array}{l}\mathrm{OP}: \mathrm{FA} \\
=8: 2\end{array}$ & 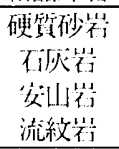 & $\begin{array}{c}25 \\
56\end{array}$ & $\begin{array}{l}150 \\
-2 \\
175\end{array}$ & $\begin{array}{c}268 \\
640\end{array}$ & $\begin{array}{c}888 \sim \\
1039\end{array}$ & $\begin{array}{c}563 \\
866\end{array}$ \\
\hline $\begin{array}{l}\mathrm{OP}: \mathrm{SF} \\
=9: 1\end{array}$ & 硬筫砂器 & 22 & 150 & 682 & 888 & 708 \\
\hline $\begin{array}{l}\text { OP }: \text { SG }: \text { SF } \\
=7: 2: 1\end{array}$ & 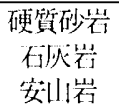 & $\begin{array}{c}15- \\
50\end{array}$ & $\begin{array}{c}150 \\
- \\
165\end{array}$ & $\begin{array}{l}330- \\
1000\end{array}$ & $\begin{array}{c}848- \\
894\end{array}$ & $\begin{array}{c}458- \\
973\end{array}$ \\
\hline $\mathrm{HP}$ & 石英片岩 & 21 & 190 & 905 & 845 & 473 \\
\hline $\begin{array}{l}\mathrm{HP}: \mathrm{SF} \\
=9: 1\end{array}$ & 石英片岩 & 16 & 150 & 938 & 879 & 459 \\
\hline $\begin{array}{l}\mathrm{HP}: \mathrm{SG}: \mathrm{SF} \\
=7: 2: 1\end{array}$ & 石英片岩 & $\begin{array}{c}16- \\
24\end{array}$ & 150 & $\begin{array}{c}626 \sim \\
938\end{array}$ & $\begin{array}{c}879 \sim \\
918\end{array}$ & $\begin{array}{c}446 \sim \\
694\end{array}$ \\
\hline
\end{tabular}

*混合比率はいずれも質量比

JIS A 1129-1「モルタル及びコンクリートの長さ変化試験方法一第 1 部：コンパレータ方法」に準じて測定を行った。なお、乾燥時の湿 度条件は長さ変化に影響するため11) 12)、本諭の実験では、いずれ の供試体も、材齢 7 日まで温度 $20^{\circ} \mathrm{C}$ 水中、それ以降を温度 $20^{\circ} \mathrm{C}$ 湿度 $60 \%$ の気中で養生している。

材齢 6 ケ月に㧍ける水結合材比と長さ变化率の関係を図 1 に示寸。 ここでは結合材の種類、粗骨材の種類、および単位水量の 3 つの要 因によってデータを分類している。

今回の実験範囲では、水結合材比が低いほど材齢 6 ケ月での長さ 変化率が小さくなる倾向と、石灰岩砕石を用いた場合にやや長さ変 化率が小さくなる傾向が見られた。この結果は、本論よりも水結合 材比の高い範囲で同様の検討を行った既往の報告 13) 14) 15) と同様で あった。また、本論の実験範囲では、水結合材比と長さ変化率の関 係に与える要因として、結合材の種類、粗骨材の種類、抒よび単位 水量の中のいずれか1つが卓越することはなかった。さらに図1の
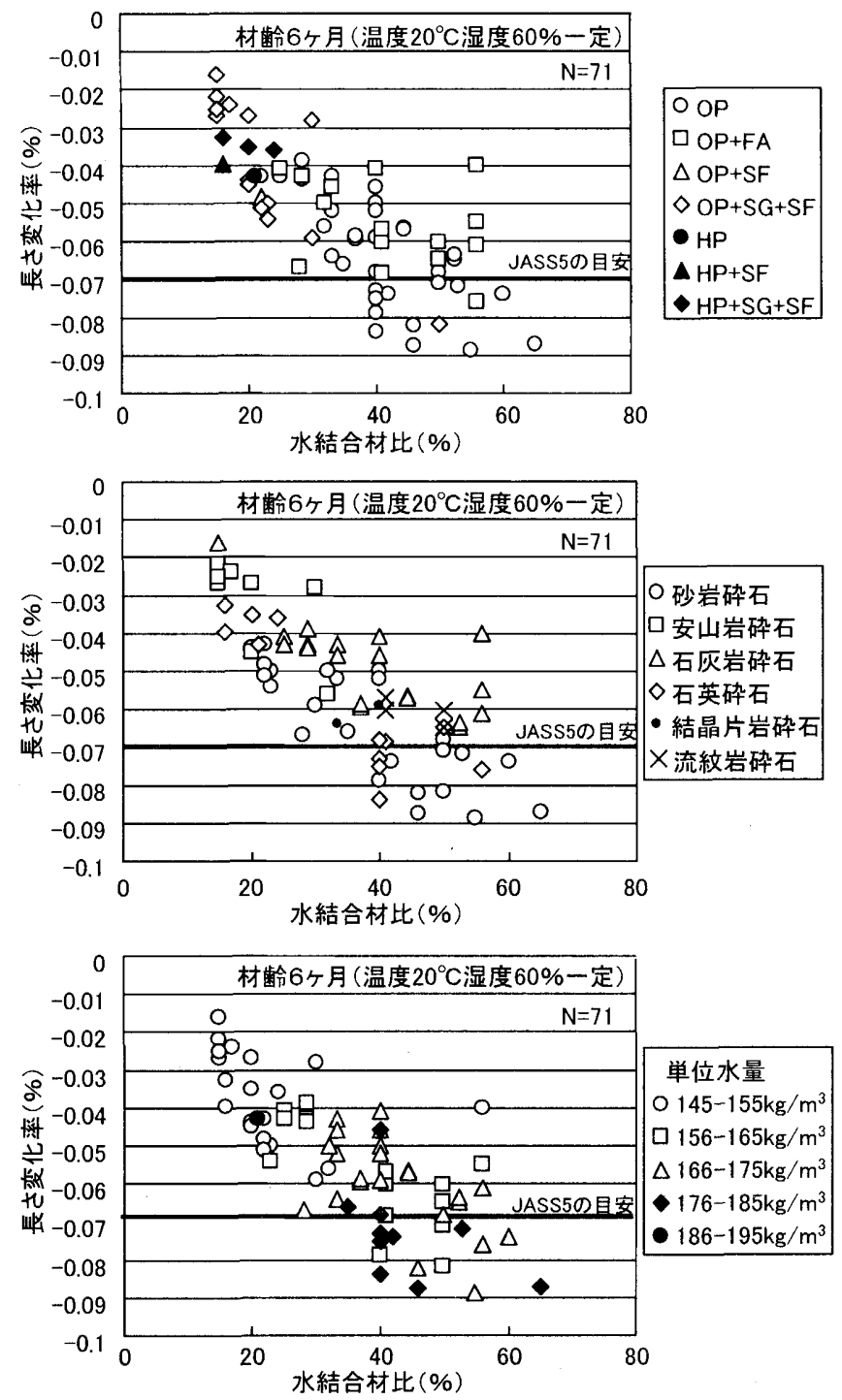

図1 材齢 6 ケ月における水結合材比と長さ変化率の関係 
結果から、JASS5（19 節）の目安となっている長さ变化 $7 \times 10^{-4}$ 以 下（0.07\%以下）のコンクリートを製造するには、使用材料と単位 水量のいずれにも配慮して調合計画する必要があると考えられた。

材齢 6 ケ月における水結合材比と質量変化率の関䌽を図 2 に示す。 コンクリートの質量変化率は、主に、コンクリート中に含まれる余 剩水の量とコンクリート中での水の移動速度に影響されると考えら れる。そこで、ここでのデータの分類は、結合材の種類と単位水量 の 2 つの要因で行った。

今回の実験範囲では、水結合材比が低いほど材龄 6 ケ月でのコン クリートの質量変化率は小さくなった。この理由としては、低水絬 合材比のコンクリートほど内部の余剩水が少ないこと、組織が緻密 で水の移動が難しいことなどが考えられる。これは、水結合材比が 低いほどコシクリートの長さ変化が小さくなることと密接に関係し ていると推察される。この理由から考えれば、而者の関係に結合材 の種類と単位水量が影響を及ぼすと考えられるが、今回の検討では、 その影響を定量的に示すことはできなかった。

\section{2 長期材齢における長さ変化}

2.10結果から考えると、コンクリ一トは、水結合材比が低く なるほど長さ変化が小さくなるのではなく、水結合材比が低くなる ほど長さ変化がゆっくり進むという可能性もある。そこで、高強度 コンクリートの長期に扔ける長さ変化率を確認するために、材齢 10 年に亘り、水結合材比 $20 \%$ 程度のコンクリートの長さ変化率と質量 変化率を測定した。

実験を行ったコンクリートの材料・調合条件を表 3 に示す。表中 には、参考として各コンクリートの材噛 28 日の標集養生圧縮強度 も示した。実験を行った調合は、ポルトランドセメント、もしくは ポルトランドセメントにスラグ石膏とシリカフュームを混合した結 合材を用いた水結合材比 $20 \sim 22 \% の 4$ 種類の調合である。また、今 回の検討では、比較用として材齢 5 年まで長さ変化を測定した水結 合材比 $65 \%$ 、単位水量 $185 \mathrm{~kg} / \mathrm{m}^{3}$ の一般的なコンクリートのデー夕 を使用した。調合を計画するにあたり、水結合材比 20 2 $22 \%$ の調合 では、コンクリートの単位水量を $150 \mathrm{~kg} / \mathrm{m}^{3}$ としたかった。しかし、 当時の化学混和剂（アミノスルフォン酸系高性能 $\mathrm{AE}$ 減水剂）の性
能では、早強ポルトランドセメントのみを用いる HP21 の単位水量 を $150 \mathrm{~kg} / \mathrm{m}^{3}$ とすることは困難であった。そこで、HP21 のみ戦位水 量を $190 \mathrm{~kg} / \mathrm{m}^{3}$ とした。

対数材齢と長さ変化率の関倸を図 3 に示す。今回の実験範囲では、 水結合材比 $20 \%$ 程度のコンクリートは材齢 100 日で 0.03 - $0.04 \%$ 程度收縮し、材齢 10.5 年までに、さらに同等の $0.02 \sim 0.04 \%$ 程度 収縮した。また、材齢 10 年が経過しても長さ変化が収束する傾向 は見られなかった。これに対し、比較用の水結合材比 $65 \%$ のコンタ リートは、材齢 100 日までに0.08\%近く収縮したが、その後、材噛 5 年までには $0.02 \%$ 程度収縮するのみであった。また、材龄 1 年程

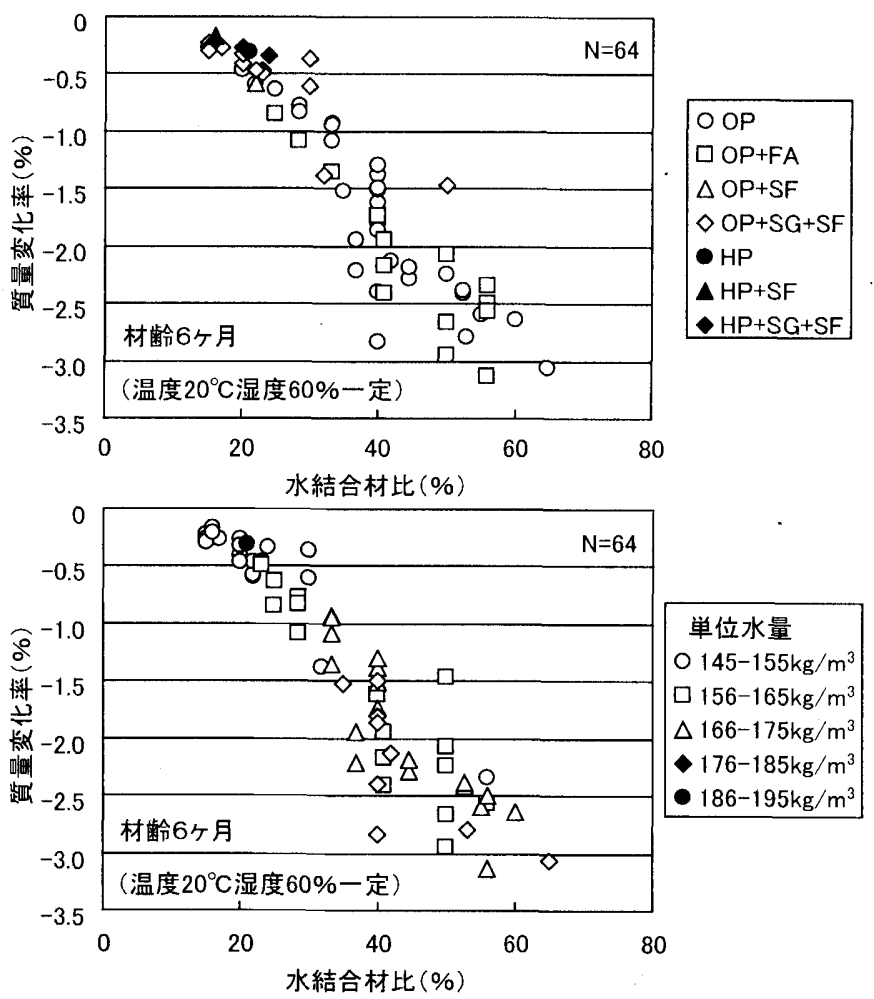

図 2 材齢 6 ケ月に扔ける水結合材比と質量変化率の関倸

表 3 材料·調合条件（長期の長さ変化試験）

\begin{tabular}{|c|c|c|c|c|c|c|c|c|}
\hline \multirow[b]{2}{*}{ 調合名 } & \multicolumn{2}{|c|}{ 材料条件 } & \multicolumn{5}{|c|}{ 調合条件 } & \multirow{2}{*}{$\begin{array}{l}\text { 標準養生 } \\
\text { 圧縮強度 } \\
\text { 材齢 } 28 \text { 日 }\end{array}$} \\
\hline & 結合材種類 & 粗骨材種類 & $\begin{array}{l}\text { W/B } \\
(\%) \\
\end{array}$ & $\begin{array}{c}\text { 単位水量 } \\
\left(\mathrm{kg} / \mathrm{m}^{3}\right) \\
\end{array}$ & $\begin{array}{c}\text { 単位結合材量 } \\
\left(\mathrm{kg} / \mathrm{m}^{3}\right) \\
\end{array}$ & $\begin{array}{c}\text { 単位細骨材量 } \\
\left(\mathrm{kg} / \mathrm{m}^{3}\right) \\
\end{array}$ & $\begin{array}{c}\text { 単位粗骨材量 } \\
\left(\mathrm{kg} / \mathrm{m}^{3}\right) \\
\end{array}$ & \\
\hline $\mathrm{OP} 22$ & $\mathrm{OP}$ & \multirow{2}{*}{ 硬質砂岩系砕石 1} & 22 & 150 & 682 & 726 & 888 & 82.6 \\
\hline OSS20 & $\mathrm{OP}: \mathrm{SG}: \mathrm{SF}=7: 2: 1$ & & 20 & 150 & 750 & 646 & 894 & 109 \\
\hline HP21 & $\mathrm{HP}$ & \multirow{2}{*}{ 石英系砕石 } & 21 & 190 & 905 & 473 & 845 & 107 \\
\hline HSS20 & $\mathrm{HP}: \mathrm{SG}: \mathrm{SF}=7: 2: 1$ & & 20 & 150 & 750 & 586 & 918 & 135 \\
\hline OP65（比較用） & $\mathrm{OP}$ & 硬質砂岩系砕石 2 & 65 & 185 & 285 & 849 & 934 & 37.5 \\
\hline
\end{tabular}

結合材： OP : 普通ポルトランドセメント (密度 $\left.3.16 \mathrm{~g} / \mathrm{cm}^{3}\right) 、 \mathrm{HP}$ : 早強ポルトランドセメント (密度 $\left.3.13 \mathrm{~g} / \mathrm{cm}^{3}\right)$ $\mathrm{SG}$ : スラグ石膏(密度 $\left.2.70 \mathrm{~g} / \mathrm{cm}^{3}\right) 、 \mathrm{SF}$ : シリカフューム(密度 $2.2 \mathrm{~g} / \mathrm{cm}^{3}$ )

粗骨材：硬質砂岩系砕石 1 ：(絶乾密度 $2.65 \mathrm{~g} / \mathrm{cm}^{2}$ 、吸水率 $0.79 \%$ )、石英系砕石：(絶乾密度 $2.60 \mathrm{~g} / \mathrm{cm}^{2} 、$ 吸水率0.64\%) 硬質砂岩系砕石 2 ：(絶乾密度 $2.62 \mathrm{~g} / \mathrm{cm}^{2}$ 、吸水率 $0.72 \%$ ) 


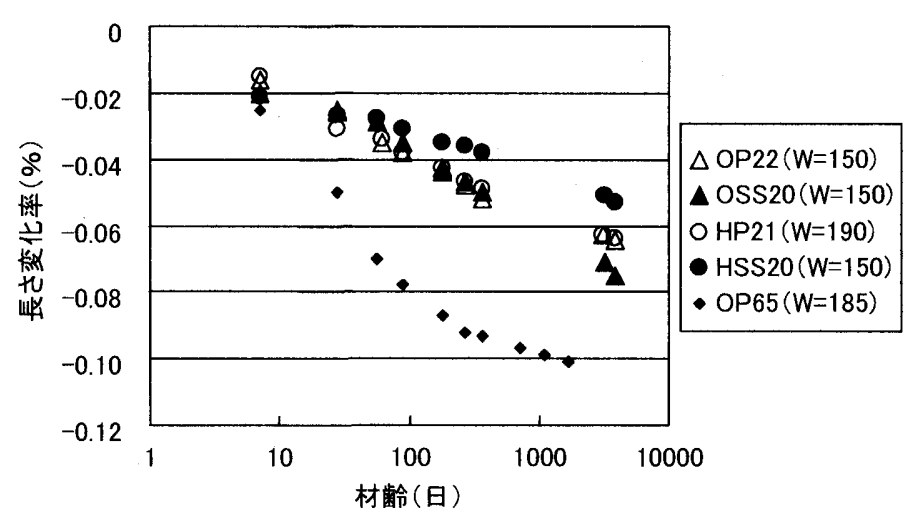

図 3 対数材龄と長さ変化率の関係

度から長さ変化が収束しはじめる傾向にあった。

対数材龄と質量变化率の関係を図 4 に示す。水結合材比 $20 \%$ 程度のコンクリートは材榆 10 年が経過しても質量変化が緩やか に進んでいるのに対し、水結合材比 $65 \%$ のコンクリートは材龄 100 日から 1000 日の間で質量変化がほぼ収束した。また、図3 と図 4 からわかるように、今回の実験範囲では、水結合材比 $20 \%$ 程度のコンクリートは、水結合材比 $65 \%$ のコンクリートに 比べて長さ変化率に対する質量变化率が小さかった。水結合材比 が低くなるにつれてセメント硬化体の長さ変化率に対する質量変 化率が小さくなるという結果については、水絬命材比 35 - $65 \%$ のセメントペーストを対象とした永松らの研究 15でも示さ机て おり、妥当な結果と考えている。

これらの結果より、コンクリートは水結合材比が低くなるほど、 より長期間に亘って収編するようになることが確認できた。今回 の実験の範囲では、低水結合材比のコンクリートの長さ変化がど の程度の材齢で収束するのか、また、この時の長さ変化はどの程 度なのかは明確にはならないが、本論の供試体を継続的に測定す ることで今後も検討を進めたいと考えている。

3. 中性化

3. 1 水結合材比と中性化深さの関係

コンクリートは水結合材比を低くして緻密になるほど中性化速 度が遅くなるとされている 17)。JIS A 1153「コンクリートの促進 中性化試験方法」に従ってコンクリートを炭酸ガスの中で養生し ても、低水結合材比の領域では、促進材齢 26 週でまったく中性 化することがない。18)そのような領域で長期の促進中性化試験 を行っても、コンクリートが中性化しなければ中性化速度係数な どを求めることはできない。そこで、まず筆者らが蓄積したコン クリートの促進中性化試験のデー夕を整理し、促進中性化試験に おける促進材秢 26 週で中性化が生じるようなコンクリートの水 結合材比の範囲を検討することとした。実験に用いる材料は、表 1 に示した長さ変化試験に用いた材料の範囲に含まれるものとし た。

検討にあたっては、フライアッシュのような混和材がポルトラ ンドセメントに比べてコンクリートの中性化抵抗性を改善する効 果が小さい19)ことを考慮した。従って、ここではコンクリート

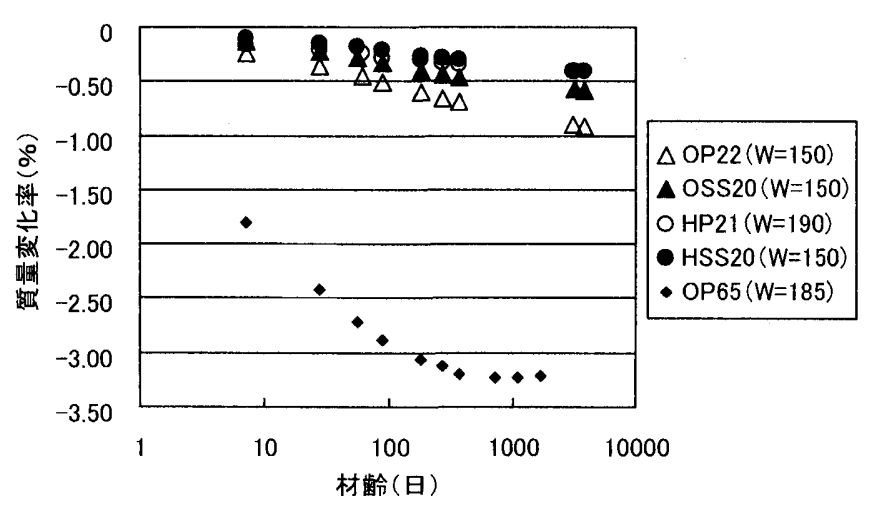

図 4 対数材齢と質量変化率の関係

表 4 調合（促進中性化試験）

\begin{tabular}{|c|c|c|c|c|c|c|}
\hline \multirow{2}{*}{ 結合材* } & \multirow{2}{*}{$\begin{array}{l}W / B \\
(\%)\end{array}$} & \multirow{2}{*}{$\begin{array}{l}\text { W/PC } \\
(\%)\end{array}$} & \multicolumn{4}{|c|}{ 単位量 $\left(\mathrm{kg} / \mathrm{m}^{3}\right)$} \\
\hline & & & 水 & 結合材 & 粗骨材 & 細骨材 \\
\hline$O P$ & $25 \sim 65$ & $25-65$ & $\begin{array}{c}155 \sim \\
185\end{array}$ & $\begin{array}{c}285 \sim \\
640\end{array}$ & $\begin{array}{c}798 \sim \\
1077\end{array}$ & $\begin{array}{c}640 \sim \\
933\end{array}$ \\
\hline $\begin{array}{l}O P: F A \\
=8: 2\end{array}$ & $25-56$ & $\begin{array}{c}31.3 \sim \\
70\end{array}$ & $\begin{array}{c}160 \sim \\
175\end{array}$ & $\begin{array}{c}214 \\
512\end{array}$ & $\begin{array}{r}888 \\
1039\end{array}$ & $\begin{array}{c}720 \sim \\
866\end{array}$ \\
\hline $\begin{array}{c}O P: S G: S F \\
=7: 2: 1\end{array}$ & $15-50$ & $\begin{array}{c}21.4 \\
71.4\end{array}$ & $\begin{array}{c}150- \\
165\end{array}$ & $\begin{array}{c}231- \\
700\end{array}$ & $\begin{array}{c}848- \\
894\end{array}$ & $\begin{array}{c}468 \\
973\end{array}$ \\
\hline $\begin{array}{r}\mathbb{I P}: S G: S F \\
=7: 2: 1\end{array}$ & 20) & 28.6 & 150 & 525 & 918 & 586 \\
\hline
\end{tabular}

*混合比率はいずれも質量比
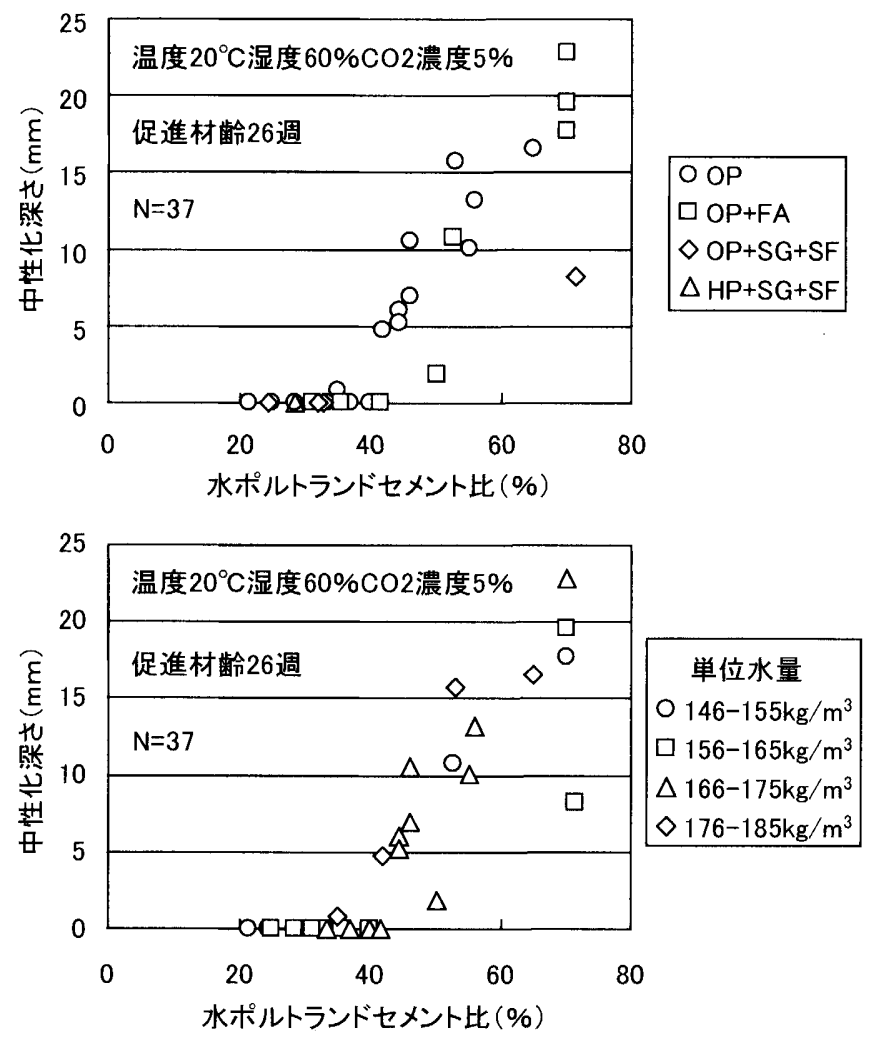

図 5 水ポルトランドセメント比と中性化深さの関係 
表 5 調合（長期促進中性化試験）

\begin{tabular}{c|c|c|c|c|c|c}
\hline \multirow{2}{*}{$\begin{array}{c}\text { W/PC } \\
(\%)\end{array}$} & \multirow{2}{*}{$\begin{array}{c}\text { スラ } \\
\text { ンプ } \\
(\mathrm{cm})\end{array}$} & \multirow{2}{*}{$\begin{array}{c}\text { 空気量 } \\
(\%)\end{array}$} & \multicolumn{4}{|c}{ 単位量 $\left(\mathrm{kg} / \mathrm{m}^{3}\right)$} \\
\cline { 4 - 7 } & & 水 & 結合材 & 細骨材 & 粗骨材 \\
\hline 40 & 10 & 3.0 & 165 & 413 & 841 & 925 \\
\hline 55 & 10 & 4.5 & 175 & 318 & 848 & 935 \\
\hline 65 & 10 & 4.5 & 185 & 285 & 849 & 934 \\
\hline
\end{tabular}

結合材：普通ポルトランドセメント (密度 $3.16 \mathrm{~g} / \mathrm{cm}^{3}$ )

細骨材：硬質砂岩系砕砂（絶乾密度 $2.56 \mathrm{~g} / \mathrm{cm}^{2}$ 、吸水率 $1.58 \%$ ） : 天然砂（絶乾密度 $2.58 \mathrm{~g} / \mathrm{cm}^{2}$ 、吸水率 $1.15 \%$ ) $=8: 2$ (質量比)

粗骨材：硬質砂岩系䂶石（絶乾密度 $2.62 \mathrm{~g} / \mathrm{cm}^{2}$ 、吸水率 $0.72 \%$ )

$1 \mathrm{~m}^{3}$ に含まれるポルトランドせメントの量と単位水量の比を水 ポルトランドセメント比 (W/PC) と定義し、デー夕の整理に用い た。な㧍、ここでのポルトランドセメントは、JIS R 5210「普通 ポルトランドセメント（5.製造方法）」に規定される 5\%の混合 物を含んだものとした。

実験を行った調合の範囲を表 4 に示す。実験に用いたコンクリ 一トは、水ポルトランドセメント比として 21.4 - 71.4\%の範囲 である。いずれのコンクリートも、日本建築学会の高耐久性鉄筋 コンクリート造設計施工指針 (案) ・同解説 ${ }^{7)}$ の付録に示されて いるコンクリートの促進中性化試験方法（案）に従って試験を行 っている。なお、本論の実験の供試体は、いずれも温度 $20^{\circ} \mathrm{C}$ の 水中で 4 週間盖生し、その後、温度 $20^{\circ} \mathrm{C}$ 湿度 $60 \%$ の気中で 4 週 間養生した後に、温度 $20^{\circ} \mathrm{C}$ 湿度 $60 \% \mathrm{C} \mathrm{O}_{2}$ 濃度 $5 \%$ の養生槽で促 進中性化を行ったものである。この方法は、2003 年に制定され た JIS A 1153「コンクリートの促進中性化試験方法」の内容と整 合している。

促進材龄 26 週での、水ポルトランドセメント比と中性化深さ の関倸を図 5 に示す。これより、今回の実験範囲では、促進材齢 26 週におけるコンクリートの中性化深さは、いずれも $25 \mathrm{~mm}$ 以下 となった。また、水ポルトランドセメント比 $40 \%$ 程度を下回る コンクリートは、促進材齢 26 週ではほとんど中性化しないと考 えられた。この結果は、既往の報告 17) 19) と概ね同様のものであ った。

\section{2 長期間促進中性化した供試体の中性化深さ}

ここまでの検討で、水ポルトランドセメント比が $40 \%$ 程度を 下回るコンクリートは、ほとんど中性化しないという知見を再確 認した。そこで、水ポルトランドセメント比 $40 \%$ 、50\%および $65 \%$ の 3 種のコンクリートについて、促進材齢 5 年までの促進中 性化試験を実施した。試験方法は 3.1 と同様である。ただし、 各調合とも供試体 6 本ずつ盖生層で促進中性化し、このうち 3 本 を長期材齢での中性化を確認するのに使用した。すなわち、材龄 6 ケ月までは前述したコンクリートの促進中性化試験方法（案） に従って 3 本の供試体を用いて中性化深さを測定し、6 ケ月以降 は残りの 3 本を用いて同試験方法（案）に準拠して中性化深さを 測定した。

試験を行ったコンクリートの材料・調合条件を表 5 に示す。い ずれのコンクリートもスランプ $10 \mathrm{~cm}$ とし、できる限りブリーデ
表 6 長期促進中性化試験結果

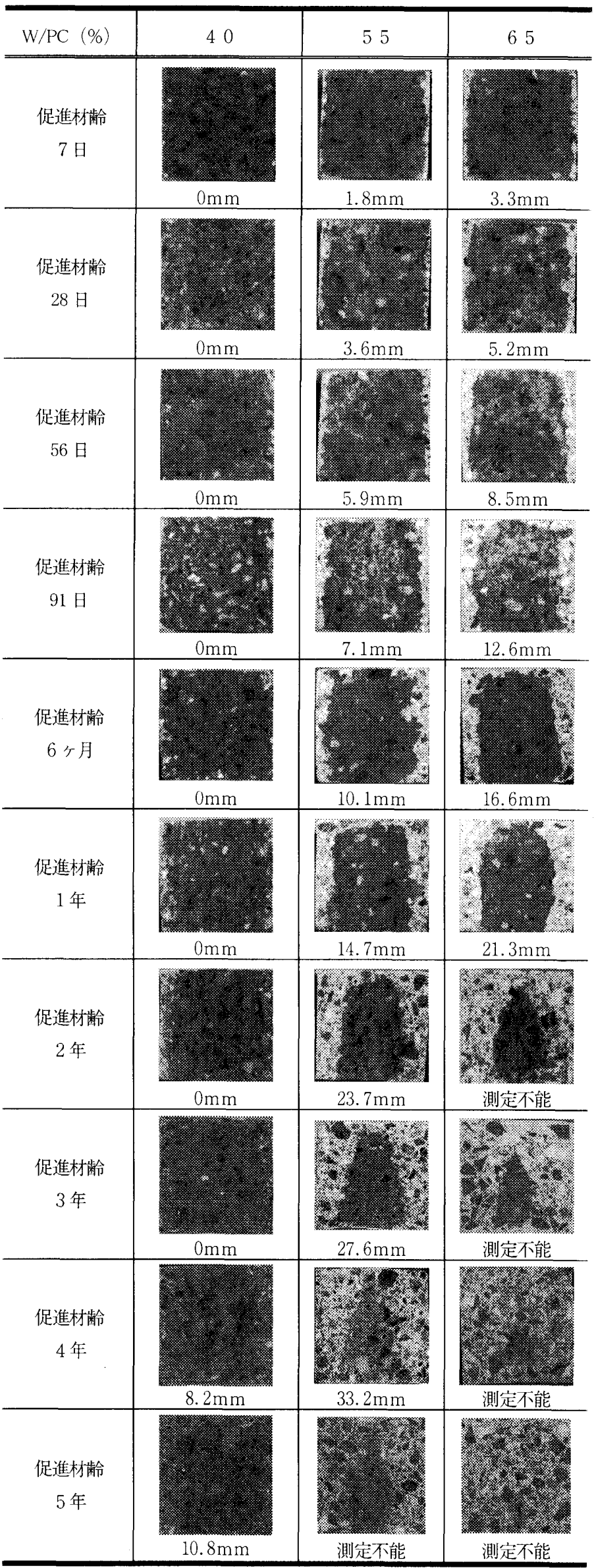


イングや沈降によって供試体が不均質となるのを避けた。また、 使用する化学混和剤も遅延効果の小さい高性能 $\mathrm{AE}$ 減水剂(ポリ カルボン酸系）在選択した。各調合とも、笁気量、単位水量など は実際に施工されているコンクリートを参考に定め、実験の共通 条件とはしなかった。

促進材齢 5 年までの促進中性化試験結果表 6 に示す。水ポル トランドセメント比 $40 \%$ のコンクリートは、促進材龄 3 年まで まったく中性化することがなかった。促進材龄 4 年ではフェノー ルフタレイン吹き付け後に、表面から $8 \mathrm{~mm}$ 程度がうす赤紫色にし か変色しなくなり、材齢 5 年ではわずかにその範囲が広くなった。 水ポルトランドセメント比 $55 \%$ のコクリートは、促進材龄 7 日 の段階で表層から $2 \mathrm{~mm}$ 程度が中性化し、材㱓の経過とともにその 範用が梁くなった。材料・調合選定の段階から供武体を均質に成 形することに十分な配虑をしたつもりであったが、促進材龄 3 年 からは供試体上部と下部の中性化深さの差が㔭著になった。本論 では、これら全体の平均を中性化哚さとした。促進材龄 5 作では 中性化深さが $50 \mathrm{~mm}$ を超え、測定することができなくなった。

$$
C=A^{\prime} \sqrt{\frac{C O 2}{5.0}} \times \sqrt{t} \quad \cdots(1) \quad A=A^{\prime} \sqrt{\frac{C O 2}{5.0}}
$$

$$
\text { ここに、 }
$$

C : 中性化深さ (mm)

$\mathrm{CO} 2: \mathrm{CO} 2$ 濃度 $(\%)$

A : 中性化速度保数 $(\mathrm{nm} \times$ 年: $1 / 2)$

$A^{\prime}$ : 促進中性化試験による中性化速度係数 $\left(\mathrm{mm} \times\right.$ 年 $\left.{ }^{1 / 2}\right)$

$t$ : 材齢 (年)

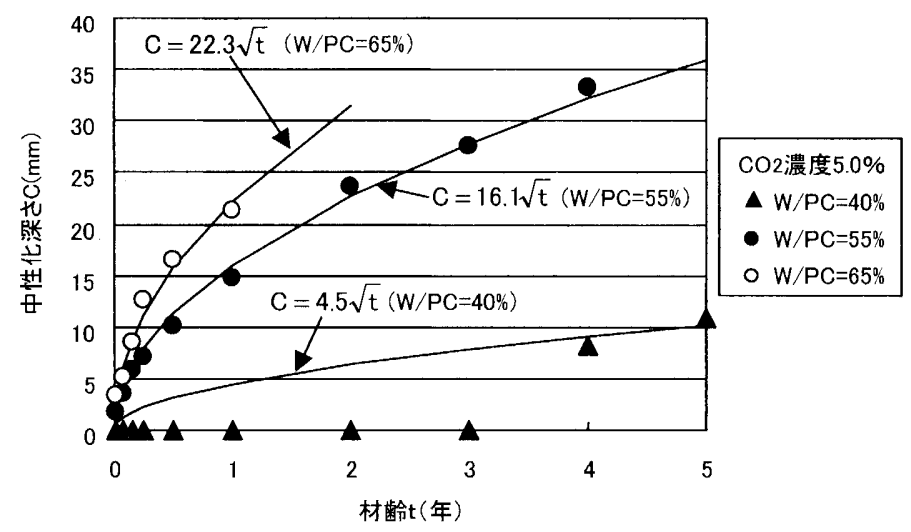

図 6 長期的な促進中性化試験による材龄 $t$ と中性化深さ $C$ の関係

表 7 長期の促進中性化試験より求めた中性化速度係数 $A(\mathrm{~m} \times$ 年 $1 / 2)$

\begin{tabular}{c|c|c|c|c}
\hline \multirow{2}{*}{$\begin{array}{c}\text { W/PC } \\
(\%)\end{array}$} & \multicolumn{4}{|c}{ 構造物のおかれる環境の $\mathrm{CO}_{2}$ 濃度 } \\
\cline { 2 - 5 } & $0.03 \%$ & $0.05 \%$ & $0.10 \%$ & $0.20 \%$ \\
\hline 40 & 0.35 & 0.45 & 0.64 & 0.90 \\
\hline 55 & 1.24 & 1.61 & 2.27 & 3.21 \\
\hline 65 & 1.72 & 2.23 & 3.15 & 4.46 \\
\hline
\end{tabular}

水ポルトランドセメント比 $65 \%$ のコンクリートは、他のコンクリー 卜よりも中性化速度が速く、促進材龄として僅か 2 年で中性化深さが 50mm を超えて測定することができなくなった。

促進材龄と中性化深さの関係を図 6 に示す。図中には中性化深 さを材龄の平方根の関数で表現する $\sqrt{t}$ 則にしたがった回㷌式も 示した。また、ここでの回帰式は、実際の建物の中性化深さを推 定しやすいように、材齢に年を代入する式とした。

図6の水ポルトランドセメント比 $55 \%$ 抢よび $65 \%$ のコンリ 一トの結果より、長期的な促進中性化試験の結果であっても、中 性化深さは $\sqrt{t}$ 則で表現できることが実験的に確認できた。また、 促進材齢 26 週までの試験であれば水ポルトランドセメント比 40\%のコンクリートは中性化しないと判断するところであるが、 今回の実験では促進材龄 4 年以降にわずかに中性化したため、本 論では水ポルトランドセメント比 $40 \%$ のコンクリートの促進材 齢と中性化深さを表現する線として、促進材龄 4 年抢よび 5 年の 結果を原点回帰した安全側の評洒線で表すこととした。

次に、この結果から実際の構造物の㧍かれる環境での中性化速 度係数 $A$ 検討した。中性化速度係数 $A$ は（2）式で表される。 検楌にあたっては、実務で用いやすいように、日本建築学会の鉄 筋コンクリー上造建築物の耐久設訃指針（案）・同解説

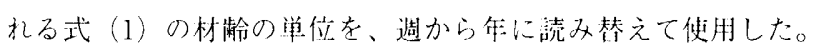

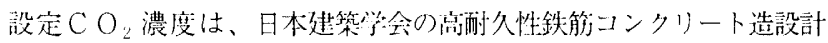

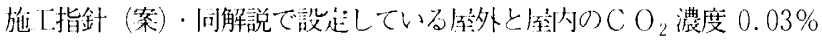
と $0.10 \%$ 、㧍よび日本建筑学会の鉄筋ニンクリート造建築物の耐久設 計施工指針 (案) - 同解説で没定してい\%屡外と屋内の $\mathrm{C} \mathrm{O}_{2}$ 濃度 $0.05 \%$ と().20\%の) 4 種類とした。

検討結果表 7 に示す。この検钨により、長期の中性化促進試 験の結果から、材齢を年単位で代入する場合の中性化速度係数 $A$ として表 7 に示す值を得ることができた。

\section{4.まとめ}

高強度コンクリートの長期的な長さ変化掞よび中性化抵抗性に 関して実験的な検討を行い、以下の結論を得た。

1）材齢 6 ケ月では、コンクリートの長さ変化や質量変化は水結 合材比が低くなるほど小さくなる傾向がみられた。

2）コンクリートは水結合材比が低くなるほど、より長期に亘っ て収縮するようになると考えられた。

3）今回の実験範囲では、促進材噛 26 週でのコンクリートの中性 化深さはいずれも $25 \mathrm{~mm}$ 以下となった。また、水ポルトランド セメント比 40\%程度を下回るコンクリートは、促進材齢 26 週ではほとんど中性化しないと考えられた。ただし、長期間 の促進試験では、水ポルトランドセメント比 $40 \%$ のコンクリ ートでもわずかに中性化することが確認された。

4）長期的な促進中性化試験の結果でも、中性化深さは材霄の平 方根の関数で表現することができた。また、材齢を年単位で 代入する $\sqrt{t}$ 則にしたがった中性化染さ推定式に用いる $\mathrm{C} \mathrm{O}_{2}$ 濃度 $0.03 \% 、 0.05 \% 、 0.10 \%$ および $0.20 \%$ の場合の中性化速 度係数 $A$ 示した。 


\section{参考文献}

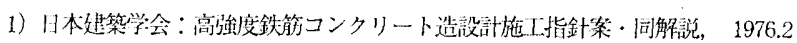

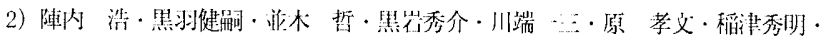

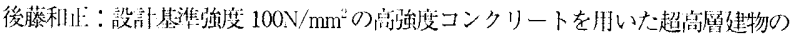

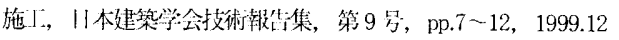

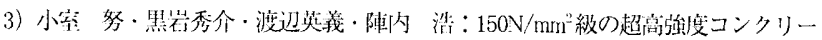

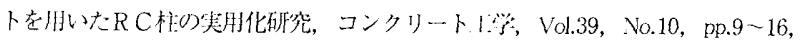
2001.10

4）(財）|目け開発技術センター：建設省総命技術開発ブロジェクト鉄筋コンクリー

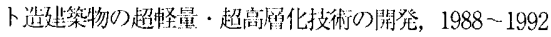

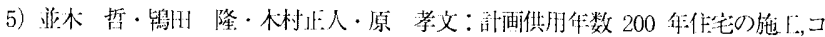
ンクリート.I学; Vol.40, No.7, pp.41〜46, 2002.7

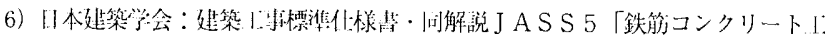
拉.], 1997

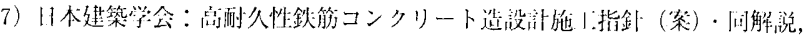
1991.7

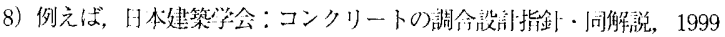

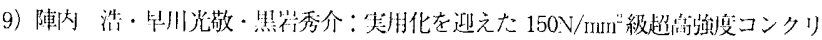
ートの性能，セメント・コンクリート，№.678, pp.10－16, 2003.8

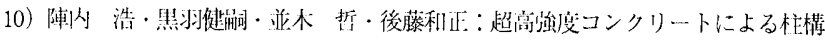

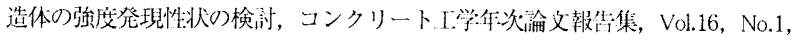
pp. $255 \sim 260, \quad 1994$

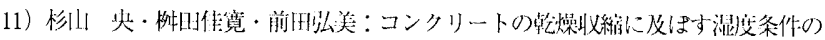
影響，セメント・コンクリート㖮文集，№.49，pp.594-599，1995
12）永松静也・位藤嘉昭・大常好籁：セメント健化体の乾燥の程度と乾燥

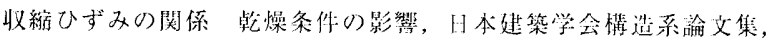
Vo.439, pp.13-21, 1992.9

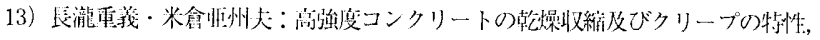
コンクリート.I\%, Vol.20, №.4, pp.75-87, 1982.4

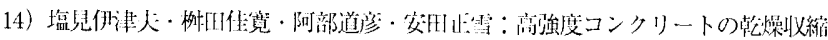

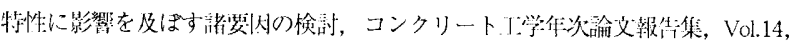
No.1, pp. $487 \sim 492,1992$

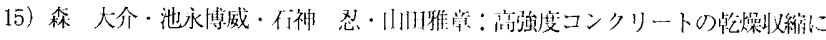
阙する研究，セメント・コンクリート筒文集，No.46， pp.690－695，1992

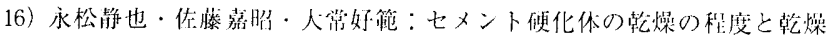

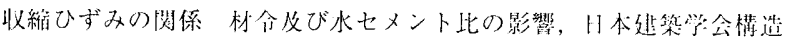
系就文集，o.451，pp.41-47，1993.9

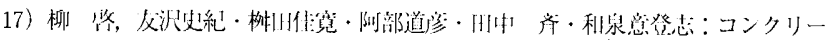

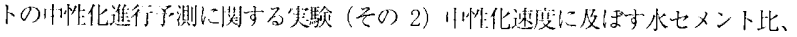

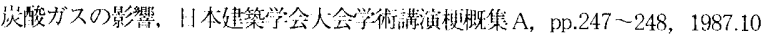

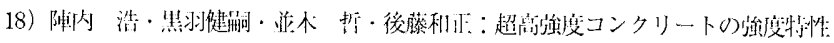

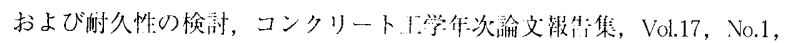
pp. 1055 -1060, 1995

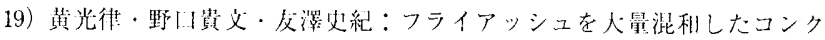

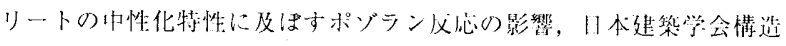
系綸文集, No.531, pp.7-14,2000.5

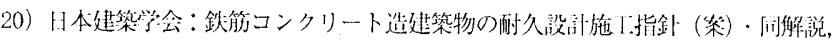
2004.3 